\title{
NEUROCYSTICERCOSIS WITH A SPACE OCCUPYING LESION: A CASE STUDY
}

Gaurav Agrawal' ${ }^{1}$ B. K. Sharma ${ }^{2}$

\section{HOW TO CITE THIS ARTICLE:}

Gaurav Agrawal, B. K. Sharma. "Neurocysticercosis with a Space Occupying Lesion: A Case Study". Journal of Evolution of Medical and Dental Sciences 2014; Vol. 3, Issue 17, April 28; Page: 4488-4490,

DOI: $10.14260 /$ jemds/2014/2463

ABSTRACT: Cysticercosis had been extremely common in South Asia, Particularly in countries like India, Bangladesh, Pakistan, Nepal etc. Most Common reason could be unhealthy practices by peoples like lack of hand washing before meals and after defecation, un properly cooked food, eating raw vegetables etc. and all these are due to lack of awareness and education. This is a case of 38 year old male from north eastern state presented with brief event of unconsciousness and seizure. On examination weakness on the left upper limb was present. Other test results also didn't conclude any significant result. On detailed history patient mentioned that 2 years back he had an episode of worm infestation for which he had taken some local treatment but the condition didn't resolve for much time. CT scan of brain showed ring enhancing small calcification with size $6 \mathrm{~mm}$. There was long latency of more than 2 years when the patient developed worm infestation and developing seizure by now.

KEYWORDS: Neurocysticercosis, Taenia Solium, Infestation, CT scans.

INTRODUCTION: Human tapeworm infection caused due to Taenia solium, is endemic in those areas where uncooked/semi cooked pork is consumed or where there is not practices for hand washing. Its prevalence is high in sub-Sahara Africa, Central and South America, India, China and parts of South East Asia. ${ }^{1}$ Cysticercosis refers to the human infection with the cysticercus stage (larva) of Taenia solium. It is acquired by accidental ingestion of eggs found in excreta of patients harboring the adult worm as a result of contamination of food and water. Cysticercosis is one of the most common parasitic diseases of the nervous system in humans especially in developing countries. ${ }^{2}$

This parasitic disease can cause a variety of neurological abnormalities, with wide presentation but the most common in all is being seizures. The most common form is neurocysticercosis which commonly presents with epilepsy, headache, personality change, and aphasia and limb weakness. About 50, 000 deaths occur due to neurocysticercosis annually throughout the world, with no less than 20 million people infected by cysticercus. ${ }^{3}$

NCC is one of the most serious problems of public health in the developing nations. It has varied clinical presentations. In the clinical setting, the diagnosis of NCC is not simple because similar clinical and radiological picture can also be present in other diseases of the central nervous system (CNS). In fact the only way of obtaining a definitive diagnosis is through surgical removal and subsequent identification of the parasite.

However this invasive method is seldom practiced, as most of these lesions carry a benign and self-limiting course. Therefore, a diagnosis of NCC is usually obtained after combining the clinical findings with radiological, serological, and epidemiological data.

The detection of antibodies against cysticercus antigens in the blood or cerebrospinal fluid is of major importance in the diagnosis of NCC. The advent of ELISA has held a lot of promise in the diagnosis of NCC. 
CASE REPORT: A 38 year old male, from north eastern state, a worker in a local dhaba of Indore, presented with the brief episode of sudden loss of consciousness and fits. This was his $1^{\text {st }}$ presentation. The episode of fits was preceded by weakness in upper part of arm and forearm on left side. He was put on phenytoin.

On examination the patient was afebrile, fully conscious, orientated and showed no neurological abnormalities EEG showed intermittent left temporal slowing without epileptic activity. Systemic investigations including full blood count, serum urea and electrolyte, chest X-ray were all normal except for the blood, which showed mild leukocytosis and eosinophilia. Lumbar puncture and stool sample analyses were negative and gave no definitive pathological results.

On detailed history patients reviled that 2 years back he had an acute abdominal pain and sever vomiting after ingestion of semi cooked pork in back home. After that he was passing smalls worms in his stool for many months for which he had taken some "local treatment".

The symptoms got subside for some time but it re occur 5 months back and it on and off, for which he has not taken any medication. Then Enzyme immunoassay test was done using purified extracts of Taenia solium antigen which came out to be strongly positive for serum IgG.

CT scan of the brain showed a small ring enhancing calcified focal area of $6 \mathrm{~mm}$ over white matter in the right parietal region. There was mild presence of cerebral edema. There were two other calcified spots on the same parts of the brain without surrounding edema. After that the patient was diagnosed as a case of neurocysticercosis of the brain.

The patient received an antiparasitic treatment with albendazole $15 \mathrm{mg} / \mathrm{kg}$ in combination with dexamethasone $4 \mathrm{mg}$ every $8 \mathrm{~h}$ for 4 weeks and phenytoin for the seizure.

DISCUSSION: The differential diagnosis of a different cystic cerebral lesion on CT or MRI includes abscess, tubercle, metastasis from various parts and glioblastoma. Parasitic CNS infections and subacute cerebrovascular events should also be considered. The clinical picture of NCC is variable with seizures, focal neurological signs, and intracranial hypertension depending on the amount and localization of the cysts. ${ }^{4}$ According to post mortem studies, $80 \%$ of neurocysticercal infections remain asymptomatic. ${ }^{5}$

Negative results on serological testing do not rule out NCC and sometimes, invasive procedures, such as surgical removal or brain biopsy, are required to confirm the diagnosis. Specific anthelminthic therapy with albendazole or praziquantel is recommended for patients with noncalcified, viable cystic lesions.6,7

The long interval between the infection and clinical symptoms of at least five years was consistent with a previous study, which reported a latency varying between a few months to 30 years, average 4.8 years. $^{8}$ The invasion of the brain by larva of Taenia solium has been known to result in a unique host-parasite immune response. ${ }^{9}$

\section{REFERENCES:}

1. Knight R. Gut cestodes. In: Weatherall DJ, Ledingham JGG, Warrell DA (eds). Oxford Textbook of Medicine, Volume 1. Oxford Medical Publishers: 1996:959-64.

2. White AC Jr. Neurocysticercosis: a major cause of neurological disease worldwide. Clin Infec Dis 1997; 24: 101-15.

3. Gemmel M, Matyas Z, Pawlowsky Z et al. Guidelines for surveillance, prevention and control of teaniasis/ cysticercosis. Geneva: WHO, 1983. 


\section{CASE REPORT}

4. Garcia HH, Del Brutto OH. Neurocysticercosis: updated concepts about an old disease. Lancet Neurol 2005, 4:653-661.

5. Rabiela-Cervantes MT, Rivas-Hernandez A, Rodriguez-Ibarra J, Castillo-Medina S, Canción FM. Cysticercosis: Present State of Knowledge and Perspective.Volume 1. Edited by Flisser A Willms K Laclette JP Larralde C Ridaura C Beltrán F. Academic Press; 1982:179-200.

6. Garcia HH, Del Brutto OH, Nash TE, White AC Jr, Tsang VC, Gilman RH. New concepts in the diagnosis and management of neurocysticercosis (Taenia solium). Am J Trop Med Hyg 2005, 72:3-9.

7. Garcia HH, Pretell EJ, Gilman RH, Martinez SM, Moulton LH, Del Brutto OH, Herrera G, Evans CA, Gonzalez AE. A trial of antiparasitic treatment to reduce the rate of seizures due to cerebral cysticercosis. N Engl J Med 2004, 350:249-258.

8. Mahajan RC. Geographical distributions of human cysticercosis. In: Flisser A, Willms K, Laclette JP, et al (eds). Cysticercosis: present state of knowledge and perspectives. New York: Academic Press, 1982:39-46.

9. White AC Jr, Robinson P, Kuhn R. Taenia solium cysticercosis: host-parasitic interactions and the immune response. Chem Immunol 1997; 66:209-30.

\section{AUTHORS:}

1. Gaurav Agrawal

2. B. K. Sharma

\section{PARTICULARS OF CONTRIBUTORS:}

1. PG Resident, Department of Pathology, Index Medical College, Indore.

2. Associate Professor, Department of Pathology, S. S. Medical College, Rewa.

\section{NAME ADDRESS EMAIL ID OF THE} CORRESPONDING AUTHOR:

Dr. B. K. Sharma, \#7/320, $2^{\text {nd }}$ Row,

Murudhar Colony, Bodabad Road,

Civil Lines, Rewa - 486001. (M. P.)

E-mail: bk_drsharma@rediffmail.com

Date of Submission: 28/03/2014. Date of Peer Review: 29/03/2014. Date of Acceptance: 10/04/2014. Date of Publishing: 23/04/2014. 